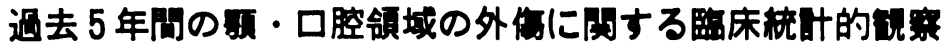

\author{
安河内 茂・伊藤友己・言屋武满・中村進 \\ 片山幹夫・三村保・宇治邦康
}

\section{Clinicostatistical observation on trauma of the oro-maxillary region during the past five years}

\author{
Shigeru Yasukouchi - Tomomi Itoh - Mitsuru Kiyan - Susum Nakamura \\ Mikio Katayama - Tamotsu Mrmura = Toshiyasu Ujr
}

\section{I. 楮}

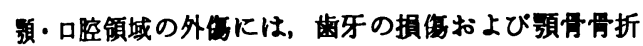

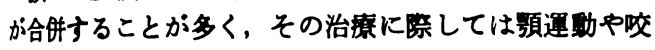

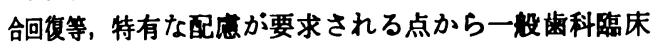
医を訪れる機会が增加してきている。

われわれは，日常齿科全般の治㞠に復わる中で過去 5 年間の頻・口腔領域の外偒患者について，臨床統計的钼 察を行ったので報告する.

\section{II. 権 察 成 績}

\section{1. 自查対象}

調査対象は, 昭和44年 1 月より同48年12月までの 5 年 間に当院を訪れた影・腔領域の外侮患者で，入院71症 例，外来96症例の計 167 症例である.

\section{2. 年度別推移}

各年度の症例数は，昭和45年に最も多く39症例 (23.4 \%)であり，昭和46年が26症例(15.6\%)で最少であっ た. 5 年間の推移は図 1 に示すとおりである.

各月別の頃度は，5月の23症例 (13.2\%) に比較的高 いよらであった（図2）.

\section{3. 年䍅およひ性別頻度}

年㱓別に钼察すると，167症例中10歳代が65症例(38.9 \%) と圧倒的に受稘率が高く，続く20歳代31症例（18.6 \%) と30歳代28症例 (16.8\%) は10歳代の半数以下であ った. また50藏以上は 8 症例(4.7\%) と稀少であった $b i, 9$ 歳以下の弱年者には比較的頻度が高く25症例(15.0

期本市宇治科医院（院長：宇治寿康）

Uji Dental Clinic, Kumamoto(Chief: Toshiyasu Uji)

受付日：昭和52年 9 月 16 日
\%)であった（図了）.

性別では，167症例中男性135症例(80.8\%)，女性32症 例 (19.2\%) と圧倒的に男性が多く，その性比は 4.2: 1 であった. しかし 9 荿以下の弱年者はおのおの14症例 と11症例で性比は 1.3：1 と男女間の顕著な差はみられ なかった.

\section{4. 受侮の原因}

受传の原因で樶も多いのが交通事故による外伤で， 167症例中57症例 (34.1\%) であった。続いて転倒（転 落や自転車の転倒による受賃む含さ)が43症例(25.7\%)， スボーツ35症例(21.0\%)，作業中事故 13 症例 (7.8\%)， 䊈力によるむの16症例(9.6\%) の順であった。このうち スポーツが原因のものは 5 年間でやや增加傾向を示し， 逆に作莱中事故による受的は減少してきている。图4 中 のその他 3 例とは歯科治嘹中の術者の操作ミスによる外 伤で，齿科用ハー・ディスクなどによって口腔周囲軟組 織（舌，口唇，煩部）を損傷した症例であるが，これら 口腔粘膜等の外伤のらち外科的処置を必要としなかった ものは含まれていない.

\section{5. 受侮部位，筑囲および程度による検討}

ここでわれわれは今回の外伤 167 症例をその受偟時の 損賃部位，筑囲および程度などから臨床的にも検討を加 之，A）影骨骨折，B）䨑槽骨骨折，C）齿牙単独の外 侮（歯牙に限局された筑囲のむの）の 3 群に区分し観察 を試みた．これらの3区分について，額骨骨折中に歯槽 骨骨折や崡牙単独の外伤が含まれ，それらが重複する症 例むあったが，今回のわれわれの統計ではその受㥂の主 体を占めるいずれかひとつの区分に含め，おのおのの重 複を避けるよらにした。これら類骨骨折，崡槽骨骨折， 雪牙単独の外伤の年度別症例数推移は図 5 に示すとおり である。

\section{A) 影骨骨折}

額骨骨折では52症例中，下䫫骨に限局した骨折が47症 例 (90.4\%) と大部分を占めており，上下䫓の合併例は 


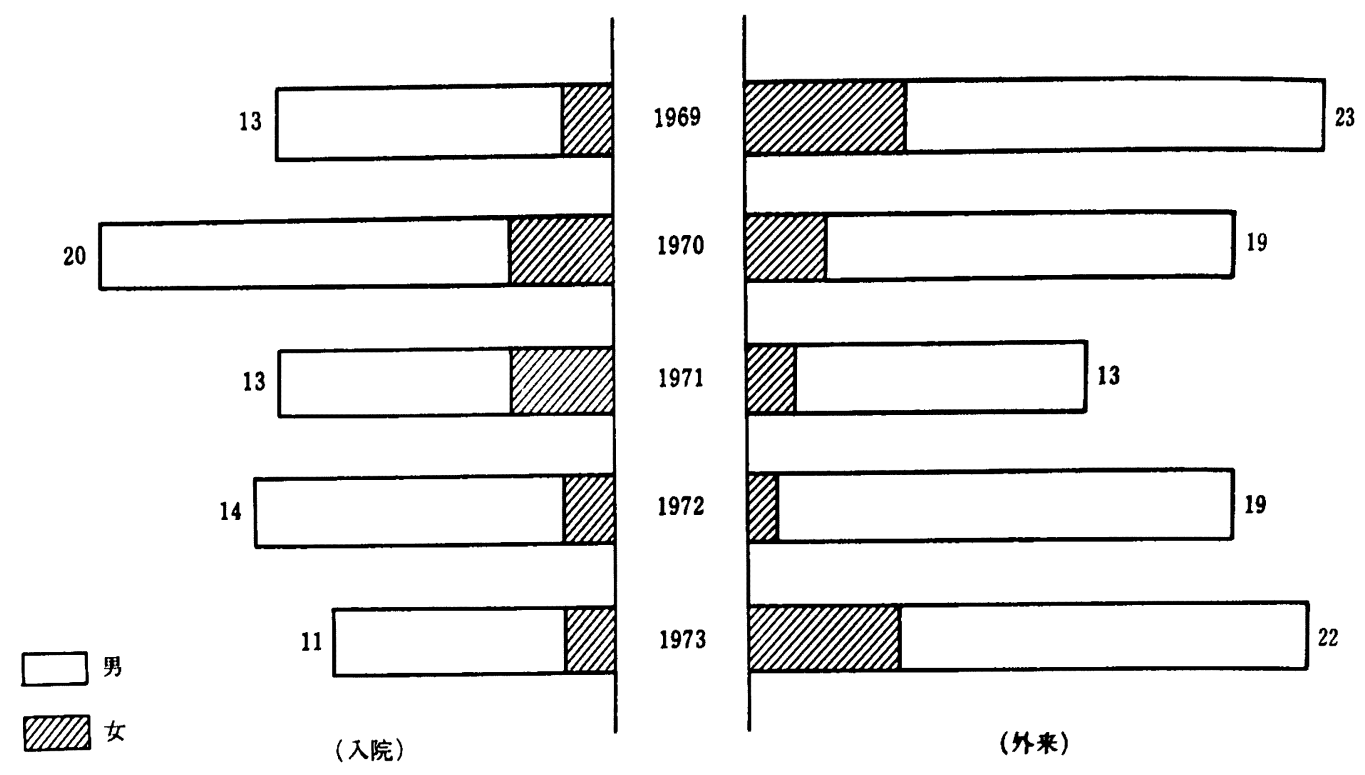

图 1 外你患者の年度別推移

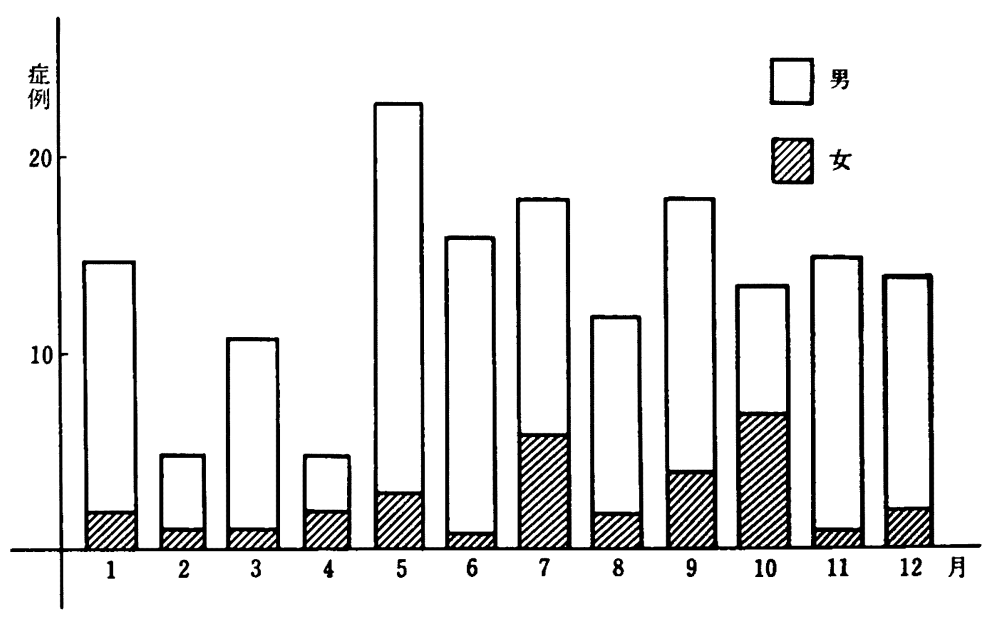

図 2 外賃患者の月別頻度

3 症例( $5.8 \%)$, 上䫑骨単独の骨折は 2 症例(3.8\%)であ った. 下顠骨骨折について骨折線は 50 症例 60 本であるが, その半数近くの29本 (48.4\%) が臨部に集中している. なお筋突起部には症例をみなかったが，関節突起部には 8 本 $(13.3 \%)$ の骨折線があった，下影骨骨折50症例中 単発骨折は38症例 $(76.0 \%)$, 重複骨折は12症例(24.0\%) で, 後者については両側 7 症例, 片側 5 症例であった。 関節突起部骨折は 8 症例にみられたが，骨体部の骨折と 重複し介達性と考えられるものは 3 症例であった（図 6 ).
下顎骨骨折を左右別に觀察すると，単発骨折では右側 8 症例, 左側 21 症例と左側に多く, 重複骨折では 5 症例 全部が左側であった。

頢骨骨折の原因は交通事故によるるのがやはり多く52 症例中32症例(61.5\%)で, 次いで暴力 9 症例(17.3\%), スボーツ 7 症例 $(13.6 \%)$ などであった. 作業中事故や 転倒が原因のものは少なく、おのおのわずか 2 症例ずつ であった(図 $7 \mathbf{A}$ ).

B）齿槽骨骨折

䨑槽骨骨折は39症例あったか，そのうち上顥が32症例 


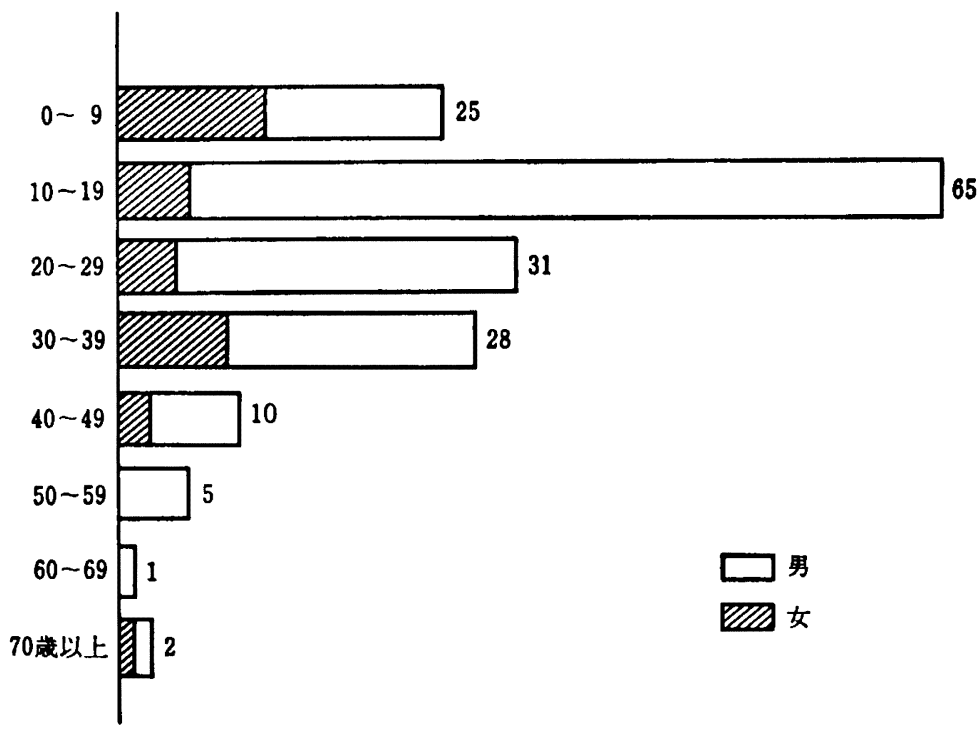

図 3 年代および性別

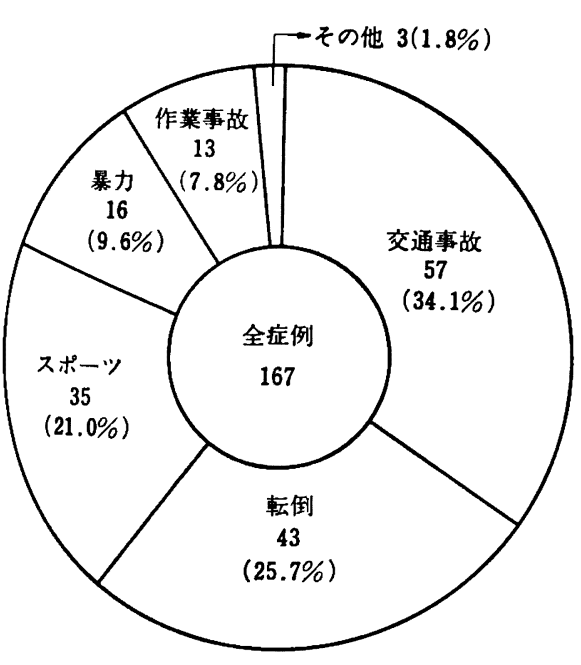

（軟組樦外借を含む）

图 4 全症例の原因別

(82.0\%)，下䫑 5 症例 (15.6\%)，上下顎合併例は， 2 症例と上額に集中し，それるほとんど前歯部であった。 これら歯槽骨骨折時における脱目（あるいは亜脱臼）， 破折齒牙は合計77歯であったが37歯はやむなく抜歯を行 い, 残り40齿の保存処置画のうち14雬に再植を試み, 26 齿は龉髄処置後あるいはそのまま整復固定し保存したも のである。

齿槽骨骨折の原因もやはり交通事故が最も多く39症例 中13应例(33.0\%)であった。 スボーツと暴力によるもの

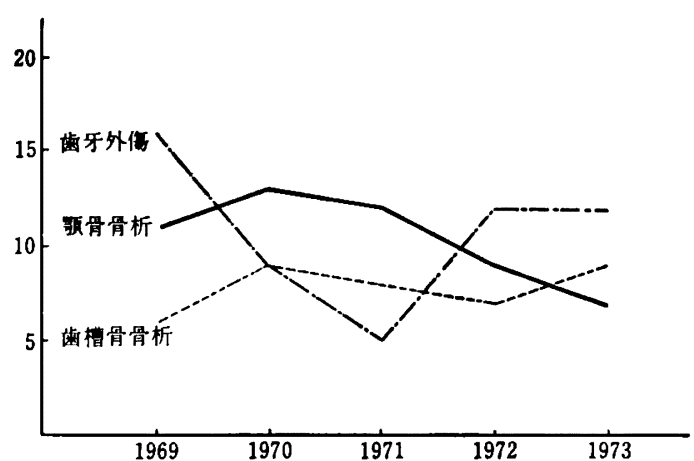

図 5 各外伤群の年度別推移

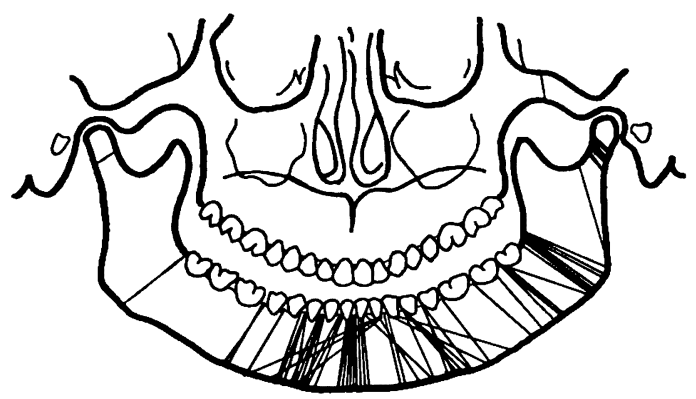

图 6 下䫅骨骨折の発生部位

は両者ほぼ同数で, 䫇骨骨折の場合と比較しスポーツに よるものの比率が高くなっていた（図７Ｂ）.

C）歯牙単独の外傷 
A. 歇情格析

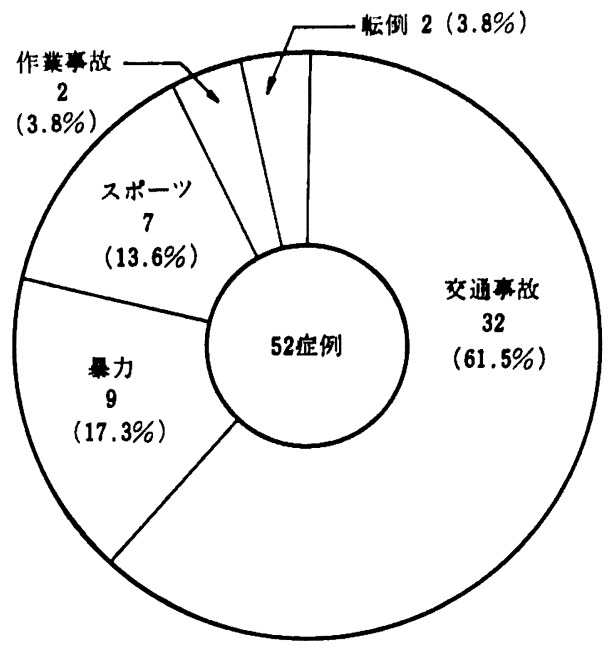

因 7 各外做群の原因別

\section{B. 蒛椣骨骨析}

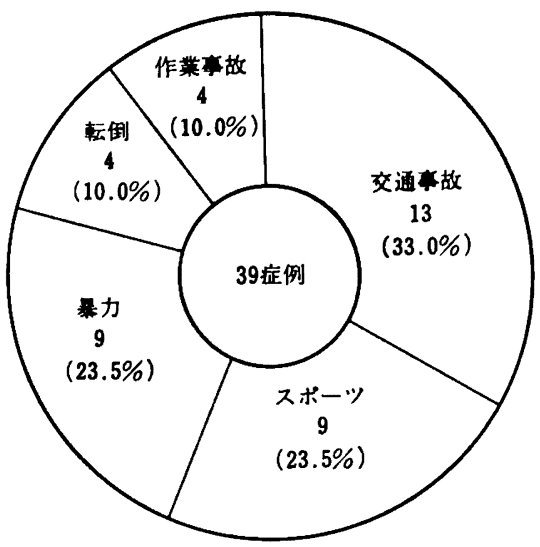

III. 苏

按

以上われわれの数所の外俉症例について钼察してき

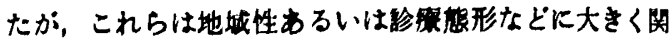
与されていると考えられる。略和44年 1 月上り同48年12 月までの 5 年間の外伤に上る入院患者71症例仕，同期間 中のわれわれの編入院患者 415 症例の $17.1 \%$ ，萑岡”

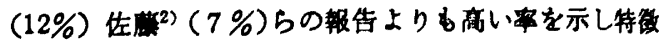

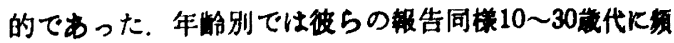

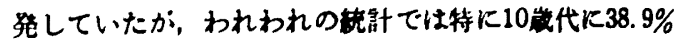
と㩆す多く，それもこの年代に年々增加の值向がるられ

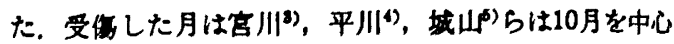

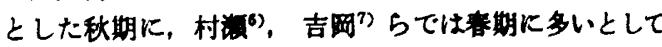

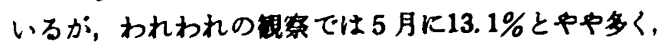
逆に 2 月，4月は3.4\%と少ないのが可りられた。

受原因については，交两事故によるるのが中はり最

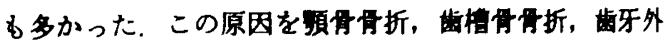
侮の各群について比較榙討してみると，影骨骨折で壮交

\section{C. 当牙外伯}

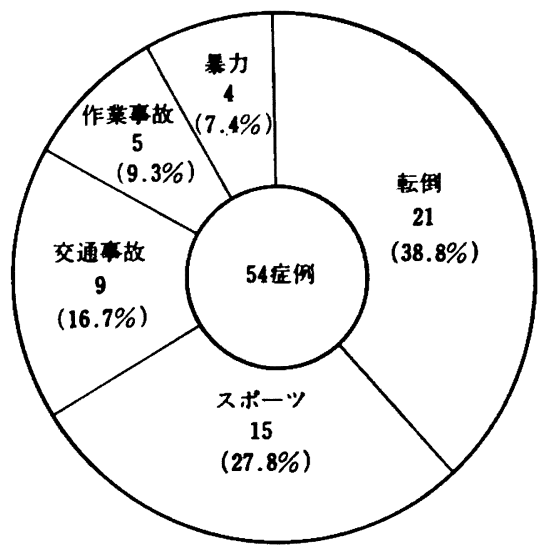

图 7 各外侮群の原因別

これもやはり上顓に多く，54症例中 48 症例 (88.9\%) で上下顎合併あるいは下顥に限られたすのは，それぞれ 2 症例， 4 症例であった。 また大小曰歯部には症例がな く前雪部たけであった．保存処固歯は45歯中40歯（88.9 \%)で再植を試みたものは8雪であった.

これらの原因をみると，頞骨骨折や歯槽骨骨折とは違 い, 転倒によるものが21症例 (38.8\%) と一番多く, 交 通事故によるむのは 9 症例 (16.7\%) と少なかった（困 $7 \mathbf{C}$ ). 通事故かi $61.5 \%$ で古屋 ${ }^{10)}(41.5 \%)$, 上野9) $(45.0 \%)$ ，小

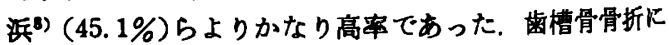
おいては交通事故は33.0\%と減少し，スボーツや暴力の 占める割合が大きくなっている，またC）の崡牙外隻群 では原因は全く入れかわり，転倒が38.8\%す占め，スボ 一ツは27.8\%，交通事故は第 3 番目でわずか $16.7 \%$ であ った.このことはわれわれの成績のA）B）C）の各外 傷群の臨床状態からす当然理解できることであろう，受 傷原因の 5 年間の変化を锶察してみると作業中事故によ 
るるのは减少し、一方スボーツによるすのは增加してい る.これは先に述べたわれわれのところの地城性や各㖒 場，工場に扣ける安全対策の充実の進步と考光られる。 さらに10代における交通外伤が增加してきていたか，こ れらはオートハイによるものが非常に多く、スボーツに

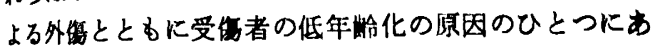
げられるよらである。

顔骨の骨折部位について，われわれの梳計では任倒的 に下䫑に多く上下顥の比は1：10であった．これらは他 の報告とも全く共通した傾向であるが，このように下湏 骨に多く発生するのは，上顥骨は頭蓋骨に保讙されてい るのに反し，下額骨は突出しており，骨折を起こしやす い解剖的形悲で外但を受けやすいためであろう。をれに 上頭骨は受傷しても頭部の外儌を併発していることが多 いことからその治㞠が優先されるため，われわれのると て処置する機会が少ないことも考えられる. しかし逆に

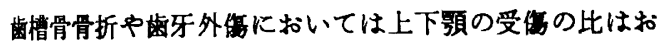
のおの4.9:1 と8.2:1 で全く上頻に多く, しかも前梅 部に集中している.これは上顥噛列が下頻のそれより突 出しており,その部分に特に受侮の際の力が集中するた めと考えられる.

下䫑骨骨折に限ってその部位別頻度を観察すると碩部 $48.4 \%$ ，骨体部 $25.0 \%$ ，偶角部 $13.3 \%$, 関節頭頸部 13.3 \%の順でほぼ他の報告と一致している. また今回のわれ われの報告では，下顥骨骨折は左側に多いことが明らか であったがこれなどは右利きの人の体位や防循反射な ど関連すると思われ興味があった。

一般に外侮は男性に多くまた年代でも青壮年期に多い とされていて，われわれの統計も男女の比は男性 4.2 に 対し女性 1 となったが，9歳以下の弱年者では男性 1.3 に対し女性 1 とは注しく性差が少なかった。このこと 清青壮年者の男女の行動態形と弱年者のそれとを比較す ると十分考えられよう。

受傷した歯牙の処置については，今回雪槽骨骨折と橉 牙単独外傷の両区分で合計 122 雪中80歯(65.5\%)が保存 処置を施しており，そのらち脱曰や脱落などのため再植 を陚みたのは22歯（保存処置歯の27.5\%) であった。 こ れらの保存処着の固定には通常三内式副木を使用したも のが多かったが，整復固定処置を迅速にするため補緅用 の Rest wire p知正用 Direct bonding system と Rectangular を応用した症例むかなりあった。 また pin implant による固定も 3 例みられた，今後ともこれらの 固定装㯰については実施臨床医が簡便に利用できるもの として取り上け゚ていきたい.

\section{IV. 結}

\section{語}

昭和44年 1 月より同48年12月に至るまでの 5 年間にわ

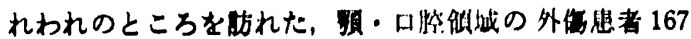

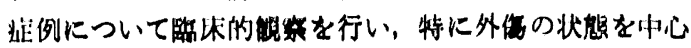
に榆村を加えた。

1. 受的者の年代は10代に压倒似に多く65店例(38.9 \%)であった，此则では男女比は4.2：1で男性に多く，

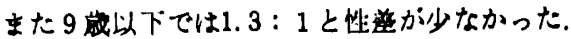

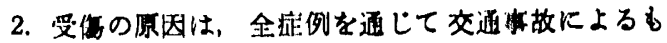

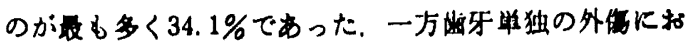
いては忶倒によるものが多く $38.8 \%$ を占めていた.

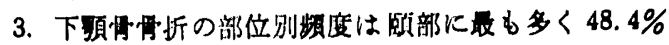

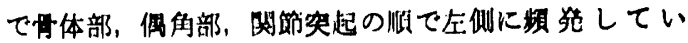
た.

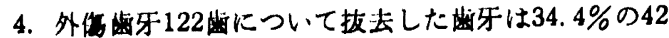

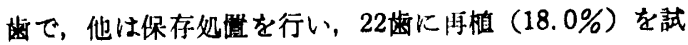
み，現在追跡調查を続けている.

なお本論文の要旨は第25回日本口腔外科学会九州地方 部会において贑演発表した。

\section{女 献}

1)藤岡幸雄, 他: 岩手医科大学菌学部口腔外科に おける創設後 5 年間の入院患者の臨床的鼣察。 口科誌 19：450 1970.

2）佐藤公彦，他：我が救室における频骨骨折患者 の統計的観察。口外誌 15：209 1969.

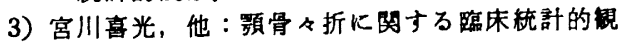
察. 口病誌 24: 3371963.

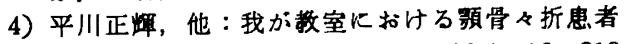
群についての梳計的钼察。齿界展望 16:910 1959.

5）城山剛彦，他：最近 5 年間のわが救空におけ

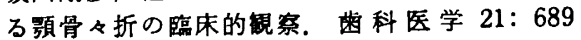
1959.

6) 村瀬正雄, 他 : 東京女子医科大学口腔外科にお ける最近 5 年間の額骨骨体骨折について. 口外 誌 8: 1421962.

7) 吉岡敏雄, 他: 新鼬大学歯科に扣ける額骨々体 骨折扣よび茵槽骨骨折の 4 年11ヶ月にわたる臨 床的翻察。口外誌 10：361 1961.

8）小泜源郁，他：下頻骨々折 317 症例に関する蹦 床的検討, 特に骨折線上の歯牙について. 口外 誌 23: 2371977.

9）上野 正：額骨骨折の原因と発生機序. 口病誌 31: 1151964.

10) 古屋英媇，他：最近13年間における本学病院を 訪れた䫓骨々折患者の㧤計的翻察. 口外誌 16 : 181970. 